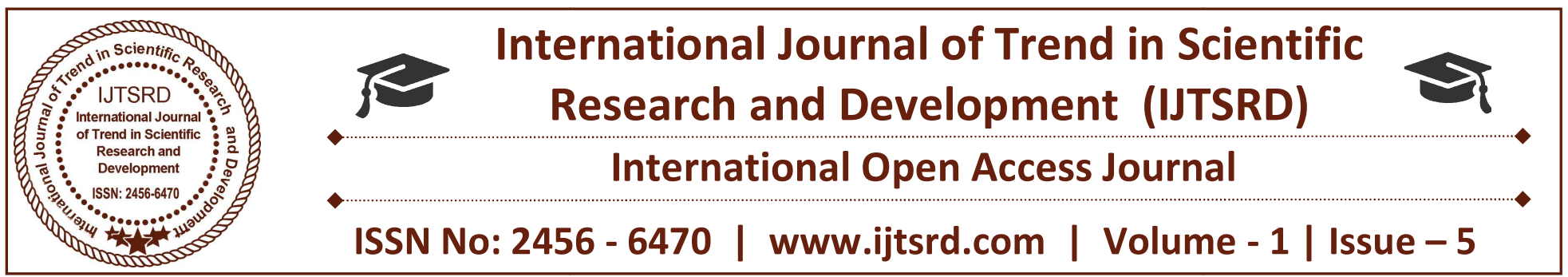

\title{
Impact of Information Technology on Global Business Strategies: Globalization Effect
}

\author{
Prof. Dr. Roshan S. Patel \\ Associate Professor \\ Faculty of Commerce, Department of Accountancy \\ Sheth C. D. Barfiwala College of Commerce, Sahyog Society, Sumul Dairy Road, Surat
}

\begin{abstract}
This study investigates the dynamic effect of information technology infusion into global business. The information technology industry is growing at a rapid pace. Information Technology [IT] is playing an ever-increasing role in supporting business strategies and transformation, with e-business lending new visibility to technology's strategic role. Information technology is a vital part of today's global economy. Indicators show that it will continue to increase in importance during the next decade. IT already impacts almost all aspects of the workplace and most of everyday life. This study will illustrate the effect of digital technology on global business.
\end{abstract}

Keywords: Information technology, global business, international business, business strategy, e-business, electronic business, technology strategy, digital technology, technological innovation, global competitiveness.

\subsection{INTRODUCTION}

Relationship Marketing (RM) is a popular concept in current marketing research and practice. RM has the potential to increase customer retention by building long-term customer relationships. RM can increase marketing effectiveness and efficiency by reducing marketing costs, facilitating the targeting of highprofit customers, reducing price sensitivity, creating opportunities for up-selling and cross-selling, erecting exit barriers, and facilitating database development (O'Malley and Tyrant, 2000). Since relationships can become an important source of competitive advantage, a marketing paradigm shift from transactional to relationship arketing has been proposed (Battle, 1996). RM was initially conceived as an approach in the business-to-business (B2B) environment. The adoption of the RM concept to consumer research is relatively new and has gone through stages from obscurity, discovery, acceptance, to popularity (O'Malley and Tyrant, 2000) While RM is powerful in theory, it is troubled in practice (Fournier et al., 1998). After years of research on RM in the consumer market, it may seem awkward that the legitimacy of the topic is still under debate.

\section{Globalization:}

Globalization can usefully be conceived as a process (or set of processes) which embodies a transformation in the spatial organization of social relations and transactions, generating transcontinental or interregional flows and networks of activity, interaction and power. Globalization is the trend toward greater economic, cultural, political and technological interdependence among national institutions and economies. It is marked by "denationalization," which is NOT "internationalization." It embraces concepts and theories from economics, political science, sociology, anthropology, and philosophy. The concept of globalization is a very recent term, only establishing its current meaning in the 1970s, which 'emerged from the intersection of four interrelated sets of "communities of practice": academics, journalists, publishers/editors, and librarians - In 2000, the International Monetary Fund (IMF) identified four 
International Journal of Trend in Scientific Research and Development (IJTSRD) ISSN: 2456-6470

basic aspects of globalization: trade and transactions, capital and investment movements, migration and movement of people, and the dissemination of knowledge. Further, environmental challenges such as global warming, cross-boundary water and air pollution, and over-fishing of the ocean are linked with globalization. Globalizing processes affect and are affected by business and work organization, economics, socio-cultural resources, and the natural environment.

\section{Globalization's effects on Business Environment:}

There is no specific event or timeline that marks when modern globalization began, because it was a gradual progression, but what needs to be remembered is that globalization means worldwide integration not just of social systems, but of political, cultural and business systems as well. It is possible to dissect each of these systems and examine the affects of globalization on them, for the sake of this paper I will only focus on its affect on the worldwide business environment. Over the past few decades there has been a sudden increase in international integration of goods, services, capital and economic activity, it is this worldwide integration that has lead us to come up with the term, globalization. Even, though this integration of worldwide markets and economies is relatively new, the evolution of globalization has had a profound affect on the global business environment. To keep this paper as "up to date" as possible I will only go over the effects of globalization at its current state of total worldwide integration when discussing the business environment.

One of the most beneficial aspects of globalization for businesses is that companies can now take skills and knowledge from across the globe and widen their horizon which leads to increased collaboration and breakthrough innovations. The ability to communicate and transfer information all around the globe lets companies focus on their main core competencies which in turn leads to better collaboration and innovation. Thomas Friedman argues, with the growing pressure of commoditization, collaboration and innovation are invaluable qualities that your company must possess. Being able to draw from experience, knowledge, skills from firms and individuals increases your chances of creating the next breakthrough product. 2 With globalization, this type of worldwide collaboration is possible, companies are now able to outsource and offshore sectors of their corporation or merge with companies from different corners of the world and are now able to communicate and transfer knowledge with almost no effort and at super-sonic speeds. There is a limitless talent pool that is out there waiting to be utilized and with globalization corporations now have the ability to use this talent.

Another major effect of globalization on business is a business' ability to empower the consumer. Now at first this may appear to have a negative impact on businesses, when in fact it does the opposite. With globalization consumers are now able to find the product that fits them best, as products are now coming from countries all over the world as the ability to communicate has grown easier and the transportation of goods has become quicker consumers can find any type, size, price, customization of the product they choose. Friedman provides a prime example of giving power to the consumer with the case of Etrade, the online bank brokerage house. What a company such as Etrade does is provide a platform for customers to view and update nearly every facet of their financial accounts, in doing so, it empowers the consumer because he or she feels that every product3, in Etrade's case their financial account information, is tailored specifically for them, when in fact all the company is providing is a platform for consumers to pick and choose what and how much information they want to view of their financial accounts. With the speeding up of information flows along with the intensifying of these flows, companies can now let consumers take control and decide on products and services that they feel are customized just for them.

Another major effect globalization has had on the business environment is that now small companies can join the global playing field? A recent IBM global study found that because of increased digital infrastructure, new wireless capabilities and changing integration of worldwide economic policies, barriers to global competition have nearly disappeared. 4 This breakdown of global barriers has given smaller companies access to distribution channels that previously were only available to large corporations. At the same time larger corporations are able to act on a smaller scale as these smaller, specialized firms enter the marketplace, larger corporations can take advantage of the flexibility and fresh outlook these new entrants present. Both sides profit as larger corporations are able to specialize to reach smaller 
International Journal of Trend in Scientific Research and Development (IJTSRD) ISSN: 2456-6470

market segments, and smaller firms have the advantage of using the expertise and size of larger corporations to grow their own company.

Globalization also leads to increased competition due to the introduction of products from countries all around the globe with the ever-increasing lower prices. It used to be that firms would only compete against firms that were geographical close and of similar size. Now with globalization, companies are competing against other companies all around the globe and of all different sizes. This growing competition also leads to what is known as commoditization, where there are so many companies with so many similar goods that a company's specific good becomes a commodity in its market because there are so many others just like it. The rate at which commoditization has occurred was unanticipated as well; just a few years ago organizations were competing against a few companies with some similar products. Now organizations are competing against companies from around the globe that provide many unique and varying products and companies now have to find a way to develop products and services that differentiate themselves from the rest of the world.

\section{IMPACT OF INFORMATION TECHNOLOGY ON GLOBALIZATION AND BUSINESS:}

In the past few sections we have defined what globalization is, its effects on society and its relationship with business. The one topic I have yet to go over is how exactly globalization is able to have this much of an impact on the global landscape and the key catalyst for globalization is, information technology. The progression towards globalization has been around for centuries, but it really became noticeable in the early 1900's with technological advances. The telegraph and telephone allowed people to communicate across borders in seconds when previously it would take weeks or months to relay messages. The invention of the airplane allowed for much quicker international travel, while communication devices such as the radio allowed people all over the globe to listen to news from all over the world in near real time. Keep in mind however, that this is not what we consider globalization today. The early 1900's were one of the major stepping stones in helping us get to our current state of globalization, but during that period there was no collective worldwide integration as many of the global processes of that time were still onedimensional. Globalization really came to being in the latter part of the 20th century with advances in information technology. Information technology was the driver in creating the worldwide integration of various global markets that make up globalization. It would again be near impossible to discuss every influential technological advance over the past 30 years, but there are a select number of advances that truly have had a monumental impact on the progression of globalization and its relationship with business.

1) Rise of the Personal Computer - The rise of the Windows-based PC, which popularized personal computing, eliminated another important barrier that was restricting globalization: the limit on the amount of information that an individual could obtain, author, modify, and distribute. The PC allowed individuals to author their own digital content and share them with places all around the world. What soon followed the PC was the invention of the dial-up modem in which users could connect to a phone line and send e-mails through service providers.

2) Invention of the World Wide Web - Perhaps the greatest influence on the progression of globalization was the invention of the World Wide Web in 1991. Before the World Wide Web, we had the internet which connected the globe, but with the World Wide Web individuals were now more than ever able to post their own digital content for anyone across the globe to see. The internet is a series of networks that sends out 'packets' of information at supersonic speeds. What made the Web so important was that it created a link between the computer and the internet. The Web made the internet useful to people. Within 5 years of the invention of the Web, internet users soared from 600,000 to 40 million. A recent study claims, "the rise in Internet use both by companies and in the population at large accelerates the pace of globalization" the internet accelerated the progress of globalization because of it allows for the sharing of knowledge and information almost instantaneously across the globe.

3) Fiber-Optic Cables - The first fiber-optic cable system was implemented in 1977, made of pure glass arranged in bundles that could be used to carry digitized packets of information. The most important benefit of the fiber-optic cable is that it has a much higher bandwidth signal capacity than other types of transmission cables. The Telecommunications act of 1996 launched an enormous boost in the laying fiber 
International Journal of Trend in Scientific Research and Development (IJTSRD) ISSN: 2456-6470

optic cables world-wide. Telecom companies saw a huge opportunity for investment in fiber-optic cables, as they felt that with the rise of the internet, people were going to be begging for increased speed and bandwidth power. As popularity continued to grow and advances on the cables continued, the capacity allowed by these cables continued to grow, making it even cheaper and easier to transmit information and digital content to any part of the world.

4) Creation of Work Flow Software - One of the first major information technology's that was geared to businesses was the creation of work flow software in the mid-1990. Work flow software is basically a software package that automates business procedures as well as being able to pass along "workflows" such as documents, information, tasks, etc...from one employee to another. When work flow software was first adopted, it enabled employees in different locations in the same company to collaborate, manage and design business data that had previously had to be handled manually.

\section{5) Digital, Mobile, Personal and Virtual Movement}

- More recently the world has been swarmed with digital cameras, mobile PDA's and cell phones along with personal laptops and this is having a profound effect on the progression of globalization. With the growing popularity of these types of technologies individuals and companies are able to collaborate with one another more frequently and in so many more ways than ever before. There are technologies such as instant messaging that allow people to communicate instantaneously, and they can be located anywhere around the world as long as they have a running internet connection and a messaging service. In this way companies can communicate with clients and employees who are around the world and give them the latest news that they may need to know in order to do business with clients or other companies. There is also a relatively new technology called Voice-Over Internet Protocol, known as VoIP, which allows you to make phone calls over the internet. An employee on a business trip now can connect their laptop to the internet, open up either the business' network or a VoIP service such as Skype and call their company or client and communicate. You may be asking why not just use a cell phone, well the main advantage of VoIP is that is it makes almost all calls virtually free, while cell phones have higher costs, especially when making international calls. Internet, open up either the business' network or a VoIP service such as Skype and call their company or client and communicate. You may be asking why not just use a cell phone, well the main advantage of VoIP is that is it makes almost all calls virtually free, while cell phones have higher costs, especially when making international calls.

\section{INFORMATION TECHNOLOGY AT THE STRATEGIC LEVEL:}

A decade ago, information technology was considered a support function to a company's success; today however, information technology has become an integral and vital component to a company's strategic planning. More and more CIO's are being asked to join other top executives when companies develop strategic plans. As the global environment continues to become more and more dynamic, the more companies must re-assess their strategic plans in order to meet the demands of the marketplace. In the realm of IT, constant re-assessment is commonplace, and because of this CIO's carry a unique ability to be able to react and make important decisions at a timely manner in order to effectively adapt to the changing environment. Other top executives are realizing this and thus making CIO's are key component to a company's strategic planning. Today companies that make information technology an integral part of their organization's strategic planning are creating a competitive advantage that is hard for other companies to overcome. FedEx, a global provider of shipping services through its network of supply chains, transportation, business and information services, has become of the leading shipping companies in the world, bringing in over $\$ 32$ billion in sales in 200617. One of the main reasons for their dominance is their continuous effort to engrain information technology into their strategic planning. For FedEx, information technology is what connects, runs, and supports their business units to provide maximum efficiency in their processes and their carrying out of strategic plans. From the early 1970's when FedEx was founded, they believed in using technology as an integral part of their strategic planning. FedEx believed that the information about shipments, was just as important as shipments themselves, and implemented a package tracking system in 1978 that created a competitive advantage for the company that lasted almost 20 years until other companies realized the importance of information technology in strategic planning. Recently in 2003, the company looked to improve business strategies through new technologies with a new initiative, FedEx called "6 x 6 Transformation". The goal of this 
International Journal of Trend in Scientific Research and Development (IJTSRD) ISSN: 2456-6470

three year project was to transform business technologies by improving on six different strategies within the company. FedEx looks to align resources to the company's critical initiatives while improving cycle time and return on investment. The viewpoint at FedEx was that even though they were generating over $\$ 20$ billion dollars in sales at that time, they still could become a more agile company that can move IT resources to fit business requirements and respond to consistently changing customer needs. The company has managed to identify that the global marketplace is dynamic and they need to transform their organization to meet the needs of this changing environment. With this IT initiative the company will only add to their company culture that looks to engrain information technology into every aspect of their organization to meet the demands of their competitive environment. The company has even created a FedEx Services business unit which provides application and infrastructure support to all of the business units and processes within the company. Business partners work continuously with IT managers to help in developing and launching new products along with creating new business strategies. This constant collaboration between IT and other business functions allows FedEx to create new business processes along with new strategies that are both technologically feasible and will create added value for the company. Technological innovations have changed how organizations do business and because of this it is a necessity for a company to make information technology a key component to their strategic planning. Because information technologies are changing how companies operate, both business and IT units must collaborate together in order to create strong and effective strategies that will help them compete in the global marketplace. Companies can no longer take a re-active approach to information technology; it is the job of CIO's to act as scouts for their organizations.

They must have the vision to see what new and upcoming technologies are worthwhile for their organization in order to effectively plan and manage new business strategies that will be the determining factor in whether or not they can survive in todays global, fast paced, ever changing business environment.

\section{SUMMARY AND CONCLUSION:}

In summary, advances in information technology have changed the way we live and have changed how people, businesses and governments interact with each other. Innovation in information technologies has played a major role in the progression of globalization over the past few decades. This expansion has had a profound impact on organizations across the globe and the only way for companies to adapt to this new environment is to make a concerted commitment to globalization through their development of processes, infrastructure, and strategies. In order to best achieve this goal companies should make information technology an integral piece to a company's global business strategy. Information technology has forever changed how organizations conduct business, as shown by my examples of companies introducing information technologies into their organization to create global strategies. As companies both large and small press forward into the future, the need for acting on a global scale becomes even more essential. Information technology is penetrating every aspect of business and without a sound IT infrastructure; companies will soon realize that they cannot keep up with the rest of their competitors making use of information technology in their firms. What organizations must remember however, is that as information technologies become cheaper to acquire, more standardized and more replicable, their ability to create value and gain competitive advantage has become lessened as more and more people have access to the same types of technologies. As these trends in information technologies continue, the market for IT will soon become a commodity market, as IT systems, services and suppliers can easily be inter-changed without loss of functionality and productivity. 18 Companies can no longer implement information technologies and expect them to create value for their organization.

\section{Reference:}

1. Anderson J.C., J.A. Narus. Partnering as a Focused Market Strategy // California Management Review, 1991, 33 (3), pp. 95-113.

2. Barnes J.G. Close to the Customer: But Is It Really a Relationship? // Journal of Marketing management, 1994, 10 (7), pp. 561-70.

3. Bennett R. Relationship Formation and Governance in Consumer Markets: Transactional Analysis versus 
International Journal of Trend in Scientific Research and Development (IJTSRD) ISSN: 2456-6470

the Behavioral Approach // Journal of Marketing Management, 1996, 12 (5), pp. 417-36.

4. Berry L.L. Relationship Marketing of Services Growing Interest, Emerging Perspectives // Journal of the Academy of Marketing Science, 1995, 23 (4), pp. 236-45.
5. Berthon P., L.F. Pitt, R.T. Watson. The World Wide Web as an Advertising Medium: Toward an Understanding of Conversion Efficiency // Journal of Advertising Research, 1996, 36 (1), pp. 43-54.

6. Bhavnagar A., S. Misra, H.R. Rao. On Risk, Convenience, and Internet Shopping Behavior // Communications of the ACM, 2000, 43 (1), pp. 98105. 